\title{
Risk-to-benefit ratio of inhaled corticosteroids in patients with COPD
}

\author{
*David Price1, Barbara Yawn², Guy Brusselle ${ }^{3}$, Andrea Rossi ${ }^{4}$ \\ Primary Care Respiratory Society UK Professor of Primary Care Respiratory Medicine, University of Aberdeen, UK \\ 2 Department of Research, Olmsted Medical Center, Rochester, Minnesota, USA \\ ${ }^{3}$ Department of Respiratory Medicine, Ghent University Hospital, Ghent, Belgium \\ ${ }^{4}$ Director, Pulmonary Unit, Vice-Director, Cardiovascular and Thoracic Department, Azienda Ospedaliera Universitaria Integrata (AOUI), \\ Verona, Italy
}

Originally received 1st February 2012; resubmitted 20th June 2012; revised 21st August 2012; accepted 20th September 2012; online 7th November 2012

\begin{abstract}
While the pharmacological management of chronic obstructive pulmonary disease (COPD) has evolved from the drugs used to treat asthma, the treatment models are different and the two diseases require clear differential diagnosis in order to determine the correct therapeutic strategy. In contrast to the almost universal requirement for anti-inflammatory treatment of persistent asthma, the efficacy of inhaled corticosteroids (ICS) is less well established in COPD and their role in treatment is limited. There is some evidence of a preventive effect of ICS on exacerbations in patients with COPD, but there is little evidence for an effect on mortality or lung function decline. As a result, treatment guidelines recommend the use of ICS in patients with severe or very severe disease (forced expiratory volume in 1 second $<50 \%$ predicted) and repeated exacerbations. Patients with frequent exacerbations - a phenotype that is stable over time - are likely to be less common among those with moderate COPD (many of whom are managed in primary care) than in those with more severe disease. The indiscriminate use of ICS in COPD may expose patients to an unnecessary increase in the risk of side-effects such as pneumonia, osteoporosis, diabetes and cataracts, while wasting healthcare spending and potentially diverting attention from other more appropriate forms of management such as pulmonary rehabilitation and maximal bronchodilator use. Physicians should carefully weigh the likely benefits of ICS use against the potential risk of side-effects and costs in individual patients with COPD.

(C) 2013 Primary Care Respiratory Society UK. All rights reserved.

D Price et al. Prim Care Respir J 2013; 22(1): 92-100

http://dx.doi.org/10.4104/pcrj.2012.00092
\end{abstract}

Keywords chronic obstructive pulmonary disease, efficacy, inhaled corticosteroids, safety

\section{Introduction}

The pharmacological treatment of chronic obstructive pulmonary disease (COPD) has evolved largely from the drugs used to treat asthma. However, the two conditions have different pathologies and the therapeutic benefits of inhaled corticosteroids (ICS) that are evident in asthma are less clear-cut in COPD. Their relative lack of efficacy in COPD and the risk of side-effects have led to recommendations for their use to be restricted to patients with more severe disease and repeated exacerbations..$^{1-3}$ Despite this, there is evidence of widespread use of ICS in patients with more moderate disease. ${ }^{4-10}$

We review here the evidence for the benefits and risks of ICS in patients with COPD. This article is based on a review of the literature (PubMed: COPD AND inhaled corticosteroids; no limits) together with the authors' clinical experience and judgement to give a representative account of the available evidence for the efficacy and safety of ICS use in patients with COPD.

\section{Importance of correct diagnosis}

The diagnosis of COPD can be suspected based on the characteristics listed in Table 1, but requires pre- and postbronchodilator spirometry testing for confirmation.

Patients with suspected COPD on the basis of symptoms, clinical and family history, and physical examination should have airflow obstruction confirmed with spirometry. The spirometric criteria for a diagnosis of COPD are a forced expiratory volume in 1 second (FEV 1 )/forced vital capacity (FVC) ratio of $<0.7$ when measured post-bronchodilator (with severity classification guided

\footnotetext{
* Corresponding author: Professor David Price, Director, Optimum Patient Care Ltd and Research in Real Life Ltd, 5a Coles Lane, Oakington, Cambridge CB24 3BA, UK. Tel: +44 (0)2081 233923 E-mail: david@rirl.org
} 
Table 1. Suggestive features for differential diagnosis of COPD and asthma ${ }^{1,12}$

\begin{tabular}{|c|c|c|}
\hline & COPD & Asthma \\
\hline Onset & Mid-life (rare before age 35) & Early life, usually childhood \\
\hline Symptoms & $\begin{array}{l}\text { Typically dyspnoea, cough, mucus production } \\
\text { Slowly progressive } \\
\text { Dyspnoea during exercise }\end{array}$ & $\begin{array}{l}\text { Typically dyspnoea, cough, chest tightness, wheeze } \\
\text { (often occurring at night or early morning) } \\
\text { Vary from day to day (can improve with removal of triggers) } \\
\text { Dyspnoea after exercise }\end{array}$ \\
\hline Smoking history & $\begin{array}{l}\text { Long history of tobacco smoking likely } \\
\text { (current or ex-smoker) }\end{array}$ & Possible \\
\hline Family history & History of obstructive airway disease increases risk & Family history of asthma or allergy increases risk 2-6-fold \\
\hline Airflow obstruction & Not completely reversible & In most instances completely reversible \\
\hline
\end{tabular}

by $\mathrm{FEV}_{1}$ as a percentage of predicted normal). ${ }^{1}$ However, an $\mathrm{FEV}_{1} / \mathrm{FVC}$ ratio of $<0.7$ is not unique for COPD and the reduction in lung function due to ageing may affect the diagnostic accuracy in older subjects. The use of alternative cut-off points such as the bottom $5 \%$ of the normal population distribution for $\mathrm{FEV}_{1} / \mathrm{FVC}$ ratio by age category (i.e. lower limit of normal) for the diagnosis of airflow obstruction in the elderly is currently under review. ${ }^{11}$

By following these diagnostic steps, the majority of cases of COPD can be clearly distinguished from those of asthma, and only a small proportion (10-15\%) of patients have mixed disease, such as individuals with hyperresponsive airways who are long-term smokers and who develop a degree of fixed airflow obstruction. ${ }^{12}$ The correct diagnosis is key to deciding the treatment strategy, which differs between asthma and COPD. ${ }^{1,13}$

\section{COPD is not asthma}

The pathobiology of airflow obstruction in COPD is unknown, but it is associated with inflammation that intensifies during exacerbations. ${ }^{14}$ Theories to explain the basis of the inflammation and other aspects of COPD such as tissue loss include accelerated ageing and autoimmunity, ${ }^{15}$ and may vary by different COPD phenotypes that are beginning to be described.

Airway inflammation in COPD is characterised by increased numbers of neutrophils, macrophages, and CD8+ T lymphocytes, with increased levels of the cytokine interleukin 8, and is largely unresponsive to corticosteroids. ${ }^{1,16}$ Asthmatic inflammation, in contrast, is dominated by eosinophils, mast cells and CD4+ T lymphocytes, and most patients with mild-tomoderate asthma are responsive to steroids or other antiinflammatory therapies such as leukotriene receptor antagonists. The small groups of non-responders are likely to include smokers and those with severe asthma. ${ }^{17}$ Conversely, eosinophilic airway inflammation may be important in the pathogenesis of severe exacerbations of $C O P D,{ }^{18}$ which may explain why ICS are effective in preventing some COPD exacerbations. In a 1-year study involving 145 COPD patients, sputum eosinophilia was associated with $17 \%$ of exacerbations and was involved jointly with bacterial and/or viral infection in a further $10 \%$ of cases. ${ }^{19}$

The treatment models in asthma and COPD are markedly different. In asthma, early anti-inflammatory treatment with an
ICS or (less frequently) leukotriene modifier is recommended for all those who require more than twice weekly use of a reliever bronchodilator. The importance of treating the underlying inflammation in asthma means that long-acting bronchodilators (salmeterol or formoterol) are used only in combination with an ICS. ${ }^{13}$ In COPD, in contrast, long-acting bronchodilators are a first-line maintenance treatment and ICS are reserved for patients with severe disease and exacerbations. ${ }^{1-3}$

\section{Effect of ICS on COPD exacerbations}

The guideline recommendations for the use of ICS in COPD are largely based on their preventive effect on exacerbations. ${ }^{1}$ In early studies evaluating the use of ICS in COPD, it was found that the group of patients most likely to benefit from the ICS fluticasone (daily dose 1,000 $\mathrm{gg}$ ) were those with more severe COPD and a history of recurrent exacerbations. ${ }^{20-22} \mathrm{~A}$ more recent systematic review by the Cochrane collaboration of trials comparing long-acting $\beta_{2}$-agonists (LABAs) and ICS concluded that the two therapies conferred similar benefits across most outcomes, including exacerbations. ${ }^{23}$ Since in most countries ICS are not indicated as monotherapy for COPD, it is important to evaluate the additional gain (and risk) obtained from adding ICS to regular bronchodilator treatment - whether LABA, longacting antimuscarinic agents (LAMA), or both.

In the 1-year TRISTAN study of fluticasone $(1,000 \mu \mathrm{g} /$ day), salmeterol, and the salmeterol/fluticasone combination, ${ }^{22}$ all active treatments reduced exacerbation rates compared with placebo, but the rates with salmeterol (1.04 exacerbations/year) and the combination (0.97 exacerbations/year) were not significantly different. Salmeterol alone was also effective in reducing both exacerbations requiring hospitalisations (labelled 'severe') and those treated as outpatients but requiring oral steroids (labelled 'moderate') in the large 3-year TORCH study $(n=6,112)$ comparing the salmeterol/fluticasone (daily fluticasone dose $1,000 \mu \mathrm{g}$ ) combination with placebo, salmeterol alone, and fluticasone alone. ${ }^{24}$ Compared with salmeterol alone, the addition of fluticasone significantly reduced the rate of moderate exacerbations but did not have any effect on severe exacerbations (Figure 1). 
Figure 1. Effect of treatment on the annual rate of exacerbations in the TORCH Study. $* * * p<0.001$ vs. placebo, * $p<0.05$ vs. placebo. $R R=$ rate ratio. Data from Calverley et al. ${ }^{24}$

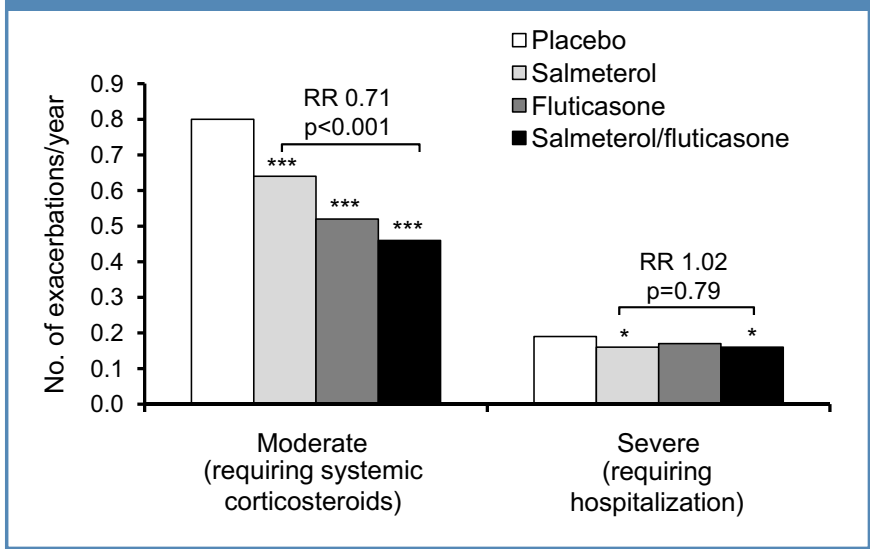

The 2-year INSPIRE study in 1,323 patients with severe or very severe COPD compared treatment with either salmeterol/fluticasone (daily ICS dose $1,000 \mu \mathrm{g}$ ) or the LAMA bronchodilator tiotropium. ${ }^{25}$ No difference in overall exacerbation rate was found between the ICS/LABA combination and tiotropium. Salmeterol/fluticasone was more effective than tiotropium at reducing exacerbations requiring oral corticosteroids, while tiotropium was more effective at reducing exacerbations requiring antibiotics.

The smaller 1-year Optimal study in 449 patients with moderate or severe COPD compared tiotropium, tiotropium plus salmeterol, and tiotropium plus salmeterol/fluticasone, and reported no significant differences between treatments in their effect on the primary outcome - the proportion of patients with exacerbations $\left(63 \%, 65 \%\right.$, and $60 \%$, respectively). ${ }^{26}$ Hospitalisations due to exacerbations were significantly reduced with the triple combination compared with tiotropium alone (incidence rate ratio 0.53). A later analysis of the study data suggested that the beneficial effect of ICS disappeared when prior ICS use was taken into account, with much of the between-group difference due to deterioration in patients in the bronchodilator treatment groups whose ICS treatment had been abruptly withdrawn at the start of the study. ${ }^{27}$

As shown in TORCH and other studies, ${ }^{22,24,25,28-30}$ treatment with a long-acting bronchodilator alone can be effective in preventing exacerbations of COPD. In terms of potential mechanisms, the reduced risk of acute exacerbations following lung volume reduction surgery suggests that improvement in bronchial calibre may in turn reduce exacerbation frequency and time to first exacerbation. ${ }^{31,32}$ Patients with the largest postoperative improvement in $\mathrm{FEV}_{1}$ had a significantly longer time to first exacerbation..$^{32}$ It appears that airway patency is an important mechanism in the prevention of exacerbations.

\section{Effect of ICS on mortality}

With regard to survival (the primary objective of the TORCH
Figure 2. Effect of treatment on probability of 3-year mortality. Data from the TORCH Study. ${ }^{24}$

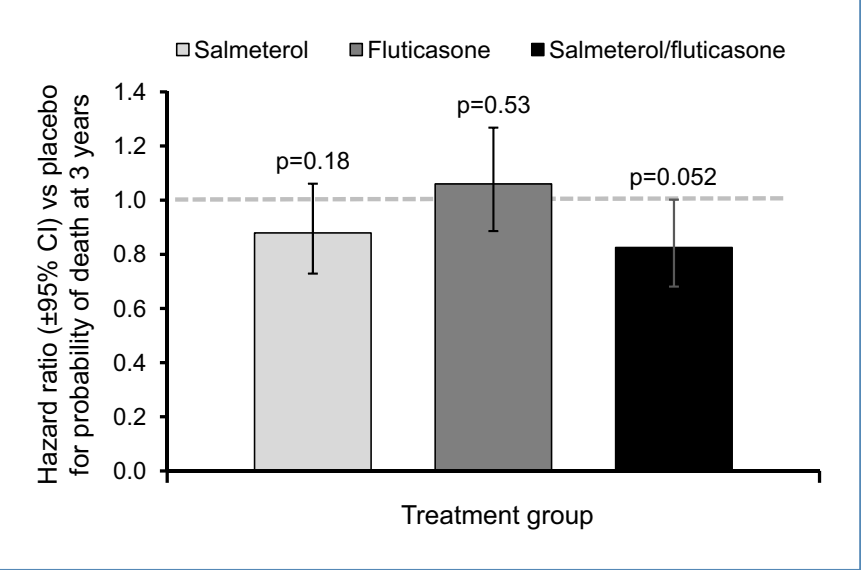

study), the effect of the salmeterol/fluticasone combination narrowly failed to reach statistical significance (mortality rate $12.6 \%$ compared with $15.2 \%$ on placebo, Figure 2). However, the addition of fluticasone did not offer additional benefit over the LABA alone (13.5\%). The hazard ratio for the combination compared with fluticasone was significant $(p=0.007)$, suggesting that the LABA might be conferring a protective effect. The TORCH results were supported by the INSPIRE study in which mortality, although not a primary outcome, was significantly reduced with salmeterol/fluticasone compared with tiotropium ( $3 \%$ versus $6 \%$ of patients during the 2 -year study). ${ }^{25}$

Several groups have suggested that most of the beneficial effect of combined salmeterol/fluticasone on mortality is due to salmeterol. ${ }^{27,33,34}$ Two groups retrospectively applied a factorial analysis to the TORCH data to determine the independent influence of salmeterol and fluticasone on mortality (i.e. any patient receiving salmeterol or fluticasone, respectively, compared with any who were not). Both analyses found that the salmeterol component was associated with a significant reduction in mortality, with a rate ratio of 0.83 (95\% confidence interval (Cl) 0.74 to 0.95$)$ and a hazard ratio of $0.81(95 \% \mathrm{Cl}$ 0.70 to 0.94 ). The fluticasone component had no effect on mortality (rate ratio and hazard ratio both 1.00). ${ }^{27,34}$

\section{Effect of ICS on rate of decline in lung function}

There is limited evidence that drug treatment can modify the rate of decline of FEV 1 in COPD. The TORCH study showed similar rates of decline of $\mathrm{FEV}_{1}$ (measured post-bronchodilator) over time with salmeterol, fluticasone, and salmeterol/ fluticasone (all $p \leq 0.003$ vs placebo), but without any difference in effect between the LABA $(-42 \mathrm{~mL} /$ year $)$, the ICS $(-42 \mathrm{~mL} /$ year $)$ or their combination $\left(-39 \mathrm{~mL} /\right.$ year) ${ }^{35} \mathrm{~A}$ recent report from the observational 3-year ECLIPSE study found that, while the annual rate of decline of $\mathrm{FEV}_{1}$ was highly variable, more than half of the 2,163 patients had a rate of decline similar to that of people without lung disease, suggesting that COPD is not invariably 
associated with accelerated decline of lung function. ${ }^{36}$ The factor most strongly associated with an increased rate of decline was current smoking, emphasising the importance of smoking cessation in the management of COPD. ${ }^{36}$

\section{Effect of ICS on health status}

In the 3-year TORCH study the addition of fluticasone to salmeterol improved the St George's Respiratory Questionnaire (SGRQ) score by 2.2 units, although the change of -3.1 over placebo was below the minimum clinically relevant difference of 4 units. In the INSPIRE study the SGRQ score was improved by 2.1 units at 2 years with salmeterol/fluticasone versus tiotropium. ${ }^{25}$ In the smaller 1-year Optimal study, the addition of fluticasone improved the SGRQ total score by 2.3 units compared with tiotropium plus salmeterol, and by 4.1 units compared with tiotropium plus placebo (respective changes from baseline were $-8.6,-6.3$, and -4.5$).{ }^{26}$ Many studies have demonstrated that monotherapy with long-acting bronchodilators - both LABA and LAMA - can provide clinically relevant improvements in health status of COPD patients, at least in the shorter term. ${ }^{37-41}$ The addition of ICS to a long-acting bronchodilator appears to improve health status by approximately 2 units.

\section{Risks of ICS for COPD patients}

While ICS have a smaller therapeutic role in COPD than in asthma, patients are more at risk from side-effects (Table 2). ${ }^{42}$ One factor is the higher doses of ICS often used in COPD, since many side-effects are dose-related. In many countries, fluticasone is licensed for use in COPD (in combination with salmeterol) at a daily dose of $1,000 \mu \mathrm{g}$, equivalent to $2,000 \mu \mathrm{g}$ of beclometasone ${ }^{13}$ or approximately $10 \mathrm{mg} /$ day of prednisone. ${ }^{43} \mathrm{~A}$ lower dose of fluticasone (250 $\mathrm{\mu g}$ twice daily) is licensed for COPD in the USA and some other countries. Patients with COPD are more likely to be older and often have several co-morbid conditions for which they receive multiple medications, making them susceptible to potential adverse effects of ICS treatment -

\begin{tabular}{|c|c|c|c|}
\hline & $\begin{array}{l}\text { Randomised } \\
\text { controlled } \\
\text { trial }\end{array}$ & $\begin{array}{l}\text { Observational } \\
\text { study }\end{array}$ & $\begin{array}{l}\text { Systematic } \\
\text { review }\end{array}$ \\
\hline Pneumonia & $\checkmark$ & $\checkmark$ & $\checkmark$ \\
\hline Tuberculosis & & $\checkmark$ & \\
\hline Bone fracture & $\begin{array}{l}\text { (No effect on } \\
\text { fracture risk) }\end{array}$ & $\checkmark$ & $\checkmark$ \\
\hline $\begin{array}{l}\text { Skin thinning/ } \\
\text { easy bruising }\end{array}$ & $\checkmark$ & & \\
\hline Cataract & & $\checkmark$ & \\
\hline Diabetes & & $\checkmark$ & \\
\hline $\begin{array}{l}\text { Oropharyngeal } \\
\text { candidiasis }\end{array}$ & $\checkmark$ & $\checkmark$ & $\checkmark$ \\
\hline
\end{tabular}

Figure 3. Adjusted rate ratios of hospitalisation for pneumonia associated with current use, past use, and dose of inhaled corticosteroid (ICS). All doses were converted to fluticasone equivalents and categorised as high (fluticasone $\geq 1,000 \mu g /$ day), moderate (fluticasone $500-999 \mu \mathrm{g} / \mathrm{day}$ ), and low (fluticasone $<500 \mu \mathrm{g} /$ day). Data from Ernst et al..$^{46}$

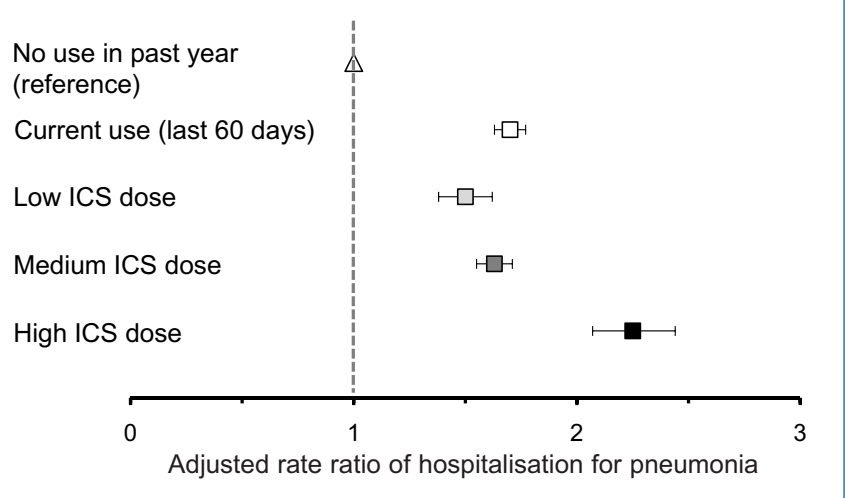

for example, skin thinning and easy bruising in patients on anticoagulant treatment and effects on bone density in patients with osteoporosis. Occasional use of systemic corticosteroids (such as steroid bursts for COPD exacerbations) increases the lifetime steroid burden and will also increase the risk of ICSrelated adverse effects.

\section{Pneumonia}

Patients with COPD are at an increased risk of pneumonia ${ }^{44,45}$ and the risks may be further increased by the use of ICS. ${ }^{24,46}$ In a large case-control study, current ICS use was associated with a 70\% increase in the rate of hospitalisation for pneumonia. ${ }^{46}$ The risk increased with ICS dose, with the use of fluticasone 1,000 $\mu$ g/day (or equivalent) more than doubling the risk of hospitalisation for pneumonia (Figure 3).

Most of the data on pneumonia come from three clinical studies reporting an increased incidence of pneumonia among fluticasone-treated patients. ${ }^{24,25,47}$ In the 3-year TORCH study ${ }^{24}$ pneumonia was reported for $19.6 \%$ and $18.3 \%$ of the fluticasone-containing arms compared with $13.3 \%$ with salmeterol and $12.3 \%$ with placebo. Risk factors for pneumonia in patients on ICS treatment included age $\geq 55$ years, $\mathrm{FEV}_{1}<50 \%$ predicted, protracted COPD exacerbations, worse dyspnoea, and body mass index $<25 \mathrm{~kg} / \mathrm{m}^{2}$. 48,49 The reported relative risk of pneumonia with ICS use in COPD ranges from 1.3 to 1.8, increasing in line with ICS dose. ${ }^{50-55}$ Budesonide was reported not to be associated with pneumonia over 1 year of use. ${ }^{56}$

The mechanism of pneumonia as an adverse effect of ICS use in COPD is not well understood but may represent blunting of the immune response in the lung, increasing susceptibility to bacterial infections. Mucoid airway occlusion of the small conducting airways may combine with steroid-induced immune suppression to increase the probability of lower respiratory tract infection. ${ }^{57}$

\section{Tuberculosis}

Immune suppression may also be involved in the link between 
steroid use and increased risk of tuberculosis among COPD patients..$^{58} \mathrm{~A}$ case-control study found that ICS did not add to the risk of tuberculosis in the presence of systemic steroids but increased the risk of tuberculosis among non-users of oral corticosteroids, especially at doses equivalent to fluticasone $1,000 \mu \mathrm{g} /$ day or more (rate ratio $1.97,95 \% \mathrm{Cl} 1.18$ to 3.3 ). ${ }^{59}$ The effect of steroids on tuberculosis is likely to be of most clinical relevance in areas where tuberculosis is common. ${ }^{60}$ Since both tuberculosis and COPD due to exposure to biomass smoke are highly prevalent in developing countries, there is an urgent need to perform interventional and/or observational studies investigating the safety of ICS in patients with COPD in these populations.

\section{Osteoporosis and risk of bone fractures}

Patients with COPD are at high risk for osteoporosis and fractures because of lifestyle factors (e.g. smoking, sedentary lifestyle), systemic effects of the disease, and co-morbidities. ${ }^{61-63}$ Osteoporosis and low bone mineral density are common even in milder stages of disease. ${ }^{63,64} \mathrm{~A}$ meta-analysis found that ICS use in COPD was associated with a modest but statistically significant increase in fracture risk. Each 500 $\mathrm{gg}$ (beclometasone dipropionate equivalent) increase in ICS dose was associated with a $9 \%$ increase in risk of fractures (Figure 4). ${ }^{65}$

The risk of osteoporosis in COPD and the seriousness of its consequences have led some to conclude that all patients with COPD, regardless of ICS treatment, should be evaluated for osteoporosis and treated with a bisphosphonate when necessary. 66,67

\section{Easy bruising}

Increased bruising has been reported in approximately $10 \%$ of COPD patients in clinical studies, together with slow healing of cuts or sores. ${ }^{68,69}$ Although probably of only modest clinical significance to the majority of patients, the skin thinning effect of corticosteroids would be of increased concern in patients on

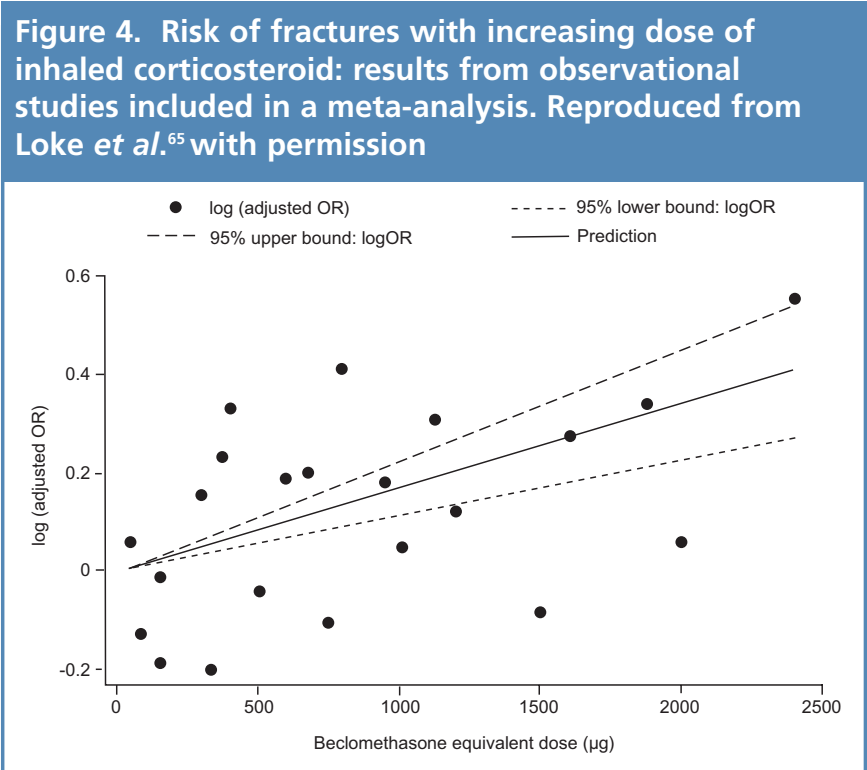

PRIMARY CARE RESPIRATORY JOURNAL www.thepcrj.org anticoagulants who are already prone to easy skin bruising.

\section{Cataracts}

Large population-based studies have shown an increased risk of posterior subcapsular cataract formation with increasing dose and duration of ICS use, ${ }^{70-73}$ although the increase in risk has not been consistently observed. ${ }^{74}$

\section{Diabetes}

A large case-control study in patients with asthma or COPD reported that ICS use was associated with a 34\% increase in the risk of both new-onset diabetes and diabetes progression. ${ }^{75}$ The risks were more pronounced (rate ratios 1.64 and 1.54, respectively) at high doses equivalent to fluticasone $\geq 1,000 \mu \mathrm{g} / \mathrm{day}$. The authors recommended that patients should be assessed for hyperglycaemia before starting high doses of ICS. ${ }^{75}$

\section{Oropharyngeal candidiasis and hoarseness}

A systematic review of studies of ICS use in COPD identified an increased risk of oral thrush (relative risk $2.98,95 \% \mathrm{Cl} 2.09$ to 4.26) and hoarseness (relative risk $2.02,95 \% \mathrm{Cl} 1.43$ to 2.83) among ICS users. ${ }^{76}$ A Cochrane review of 47 primary studies similarly reported an increased risk of oropharyngeal candidiasis (odds ratio $2.49,95 \% \mathrm{Cl} 1.78$ to 3.49 ) and hoarseness. ${ }^{.7}$ The TORCH study reported rates per year of candidiasis of $0.7-0.9$ with fluticasone-containing treatment compared with 0.2 for salmeterol and placebo groups. ${ }^{24}$

\section{Which COPD patients will benefit from an ICS?}

Two groups of COPD patients appear likely to benefit most from ICS treatment. The first is the minority with mixed asthma and COPD, given the need to avoid using LABA monotherapy in patients who might have asthma. The second is those COPD patients who are frequent exacerbators despite optimal bronchodilator treatment, a phenotype that may involve increased eosinophilic (asthma-like) inflammation. ${ }^{19}$ COPD patients with identified sputum eosinophilia who received increasing doses of ICS and oral corticosteroids according to eosinophil levels, in a strategy designed to reduce eosinophilic airway inflammation, had a significant reduction in exacerbations compared with patients treated according to traditional guidelines. ${ }^{18}$

The definition of COPD patients as frequent exacerbators is based on expert opinion rather than a rigorous phenotypic assessment. Thus, frequent exacerbations are defined as $\geq 2 / y e a r$ by the Global Initiative for Chronic Obstructive Lung Disease (GOLD) ${ }^{1}$ as well as the ECLIPSE study investigators. ${ }^{78}$ The single best predictor of exacerbations across all GOLD stages is a history of exacerbations. ${ }^{78}$

The frequent exacerbator phenotype is less common among patients with moderate COPD than in those with more severe disease. In the ECLIPSE study, frequent exacerbations ( $\geq 2 /$ year) occurred in $22 \%$ of patients with GOLD stage 2 disease (moderate), 33\% with stage 3 (severe), and $47 \%$ with stage 4 
(very severe). ${ }^{78}$ Baseline data on exacerbation history from patients in the TORCH study also suggested an increase in the frequency of exacerbations with increasing COPD severity. ${ }^{79}$ Furthermore, more than half (56\%) of the patients followed in the ECLIPSE study had $\leq 1$ exacerbation in the first year. Of these, $83 \%$ continued to have $\leq 1$ exacerbation in the next year. Exacerbation frequency was relatively stable over time, especially patients who had no exacerbations (more than $40 \%$ of patients in the first year). ${ }^{78}$ However, these estimates of exacerbation frequency are not derived from representative samples of those patients seen mainly in primary care, and the estimate of about one in five frequent exacerbators among those with moderate COPD - who make up the majority of those typically managed in primary care - requires confirmation in the appropriate population. It is also important to note that the identification of the frequent exacerbator phenotype in the ECLIPSE study did not focus on medication as a determinant of exacerbations (use of any LABA or any ICS was self-reported by $>70 \%$ of patients). ${ }^{78}$

\section{Patients already on ICS}

Careful withdrawal of ICS may be appropriate, especially for patients at high risk of side-effects. Patients may be receptive to such an approach, since only about half of COPD patients persist with ICS for more than a year ${ }^{80}$ and adherence, particularly among the elderly, may be low. ${ }^{81}$ Studies examining the effect of ICS withdrawal reported some deterioration in disease control. ${ }^{82-85}$ However, a recent meta-analysis highlighted methodological flaws in evaluable studies of ICS withdrawal in COPD and calculated that withdrawal of ICS resulted only in a small and insignificant increase in exacerbations. ${ }^{86}$ Nevertheless, a preferable approach would be to ensure the correct treatment strategy from the outset, with the use of ICS reserved for patients in whom the benefit will outweigh the risk.

\section{Place of ICS in COPD treatment guidelines}

Evidence-based guidelines support a limited role for ICS in COPD treatment. ${ }^{1,2}$ According to global COPD guidelines, the use of an ICS in combination with a LABA is appropriate for patients with higher risk, defined as GOLD stage 3 or 4 (severe or very severe airflow limitation) and/or frequent exacerbations. ${ }^{1}$ A recent US/European clinical practice guideline found strong evidence for the use of long-acting bronchodilator monotherapy for symptomatic patients with $\mathrm{FEV}_{1}<60 \%$ predicted. The evidence was judged too weak to support a strong recommendation for the broad use of combination therapy (LABA and ICS) in these patients, and clinicians were advised to weigh the potential benefits and harms of combination therapy on a case-by-case basis. ${ }^{2}$ Based on cost-effectiveness analysis and 'inconclusive' clinical evidence of effectiveness of LABA/ICS (versus LABA alone) in more severe COPD, the UK National Institute for Health and Clinical Excellence (NICE) guidelines recommended the LABA/ICS combination as an option (alongside LAMA monotherapy as the other option) for patients with $\mathrm{FEV}_{1}<50 \%$ predicted (GOLD stage 3 or 4 ) with exacerbations or breathlessness. ${ }^{3}$ However, the evolving evidence reviewed here suggests that some guideline recommendations may merit review, including the NICE recommendation to consider LABA/ICS for symptomatic patients treated with a LAMA, irrespective of their $\mathrm{FEV}_{1}{ }^{3}$

Many current guidelines set out treatment recommendations according to severity staging based on different ranges of $\mathrm{FEV}_{1}$ percentage predicted. Since COPD is a progressive disease and divisions around the cut-off values of $\mathrm{FEV}_{1}$ are to some extent arbitrary, the treating physician will also need to consider broader aspects of disease severity when choosing treatment for a particular patient. The recently updated GOLD guidelines include symptom burden and exacerbation frequency for severity staging, as well as airflow obstruction. ${ }^{1}$ Factors such as quality of life, exacerbations and co-morbidities, and their relative impact on the patient's lifestyle, as well as patient preference and the risk of side-effects of treatment, should also be taken into account.

\section{Conclusions}

Correct diagnosis at the outset is essential to deciding treatment strategy. ICS have valuable beneficial effects in asthma that are less apparent in COPD, where these agents have an important but much more limited role in treatment. The use of high doses of ICS and the patients' typically older age and frequent co-morbidities put COPD patients at increased risk of ICS-associated side-effects, many of which are far from trivial. Thus, the potential benefits and risks of ICS treatment need to be weighed for individual patients and their use reserved for those patients who are clearly most likely to benefit - that is, those with severe COPD with repeated exacerbations and the 10-15\% of COPD patients with mixed asthma and COPD. Patients with frequent exacerbations are identifiable from their history of exacerbations, and exacerbation frequency is fairly constant over years. Many patients being managed in primary care have moderate disease and many patients - especially those with moderate COPD - do not experience frequent exacerbations. Currently available long-acting bronchodilators (both LABAs and LAMAs) have demonstrated efficacy for exacerbation prevention, and we endorse the guideline approach to treat with one or more long-acting bronchodilators in patients with COPD before using ICS.

\section{Handling editor Irem Patel}

Acknowledgements Sarah Filcek (CircleScience, UK) prepared a first draft of the manuscript and coordinated the authors' input into this and subsequent drafts.

Conflicts of interest DP has consultant arrangements with Almirall, AstraZeneca, Boehringer Ingelheim, Chiesi, GlaxoSmithKline, Merck, Mundipharma, Novartis, Pfizer, Sandoz and Teva. He or his research team has received grants and support for research in respiratory disease from the following organisations in the last 5 years: UK National Health Service, Aerocrine, AstraZeneca, Boehringer Ingelheim, Chiesi, GlaxoSmithKline, Merck, Mundipharma, Novartis, Nycomed, Pfizer and Teva. He has spoken for Almirral, AstraZeneca, Boehringer Ingelheim, Chiesi, Cipla, GlaxoSmithKline, Kyorin, Merck, Mundipharma, Pfizer and Teva. He has shares in AKL Ltd which produces phytopharmaceuticals. He is the sole owner of Research in Real Life Ltd.

Within the past 36 months BY has received research funding for studies in COPD from 
BI-Pfizer, Novartis, Merck and has served on the COPD advisory board for future phase 4 studies for BI-Pfizer and Novartis. She has also received funding from NHLBI and ATS related to spirometry use for COPD in primary care practice.

$\mathrm{GB}$ has, within the last 5 years, received honoraria for lectures from AstraZeneca, Boehringer-Ingelheim, Chiesi, GlaxoSmithKline, MerckSharp\&Dohme, Novartis, Pfizer, and UCB. He is a member of advisory boards for AstraZeneca, Boehringer-Ingelheim, GlaxoSmithKline, and Novartis.

AR has received reimbursement for attending symposia, fees for speaking, fees for organising education, funds for research, and fees for consulting from AstraZeneca, Boehringer/Pfizer, Chiesi, GlaxoSmithKline, Novartis, and Nycomed/Tanaka.

Contributorship All authors were involved in the concept and design of this article. All authors revised the article critically for important intellectual content and gave their final approval of the version to be published.

Funding Writing assistance was funded by Novartis Pharma AG (Basel, Switzerland).

\section{References}

1. Global initiative for chronic obstructive lung disease (GOLD). Global Strategy for the Diagnosis, Management, and Prevention of Chronic Obstructive Pulmonary Disease. Updated 2011. www. goldcopd.com (accessed 21 Sep 2011).

2. Qaseem A, Wilt TJ, Weinberger SE, et al. Diagnosis and management of stable chronic obstructive pulmonary disease: a clinical practice guideline update from the American College of Physicians, American College of Chest Physicians, American Thoracic Society, and European Respiratory Society. Ann Intern Med 2011; 155(3):179-91

3. National Institute for Health and Clinical Excellence. CG101 Chronic obstructive pulmonary disease (update): full guideline. 18 Jan 2012. http://guidance.nice.org.uk/CG101/Guidance/pdf/English (accessed 23 May 2012).

4. Suissa S, Barnes PJ. Inhaled corticosteroids in COPD: the case against. Eur Respir J 2009;34(1):13-16. http://dx.doi.org/10.1183/09031936.00190908

5. Jochmann A, Neubauer F, Miedinger D, Schafroth S, Tamm M, Leuppi JD. General practitioner's adherence to the COPD GOLD guidelines: baseline data of the Swiss COPD Cohort Study. Swiss Med Wkly 2010;140:w13053. http://dx.doi.org/ 10.4414/smw.2010.13053

6. Jebrak G; Initiatives BPCO. [COPD routine management in France: are guidelines used in clinical practice?]. Rev Mal Respir 2010;27(1):11-18. http://dx.doi.org/ 10.1016/J.rmr.2009.08.002

7. Lucas AE, Smeenk FW, Smeele IJ, van Schayck CP. Overtreatment with inhaled corticosteroids and diagnostic problems in primary care patients, an exploratory study. Fam Pract 2008;25(2):86-91. http://dx.doi.org/10.1093/fampra/cmn006

8. Bourbeau J, Sebaldt RJ, Day A, et al. Practice patterns in the management of chronic obstructive pulmonary disease in primary practice: the CAGE study. Can Respir J 2008;15(1):13-19

9. Fitch K, Iwasaki K, Pyenson B, Plauschinat C, Zhang J. Variation in adherence with Global Initiative for Chronic Obstructive Lung Disease (GOLD) drug therapy guidelines: a retrospective actuarial claims data analysis. Curr Med Res Opin 2011;27(7):1425-9. http://dx.doi.org/10.1185/03007995.2011.583230

10. Corrado A, Rossi A. How far is real life from COPD therapy guidelines? An Italian observational study. Respir Med 2012;106(7):989-97. http://dx.doi.org/ 10.1016/j.rmed.2012.03.008

11. Price $D$, Crockett $A$, Arne $M$, et al. Spirometry in primary care case-identification, diagnosis and management of COPD. Prim Care Respir J 2009;18(3):216-23. http://dx.doi.org/10.4104/pcri.2009.00055

12. Price $\mathrm{DB}$, Yawn BP, Jones RC. Improving the differential diagnosis of chronic obstructive pulmonary disease in primary care. Mayo Clin Proc 2010;85(12):1122-9. http://dx.doi.org/10.4065/mcp.2010.0389

13. Global Initiative for Asthma (GINA). Global Strategy for Asthma Management and Prevention. Updated December 2010. http://www.ginasthma.org/ (accessed 21 Sep 2011).

14. Brusselle GG, Joos GF, Bracke KR. New insights into the immunology of chronic obstructive pulmonary disease. Lancet 2011;378(9795):1015-26. http://dx.doi.org/ 10.1016/S0140-6736(11)60988-4

15. Sharma G, Hanania NA, Shim YM. The aging immune system and its relationship to the development of chronic obstructive pulmonary disease. Proc Am Thorac Soc 2009;6(7):573-80. http://dx.doi.org/10.1513/pats.200904-022RM

16. Barnes PJ. Future treatments for chronic obstructive pulmonary disease and its comorbidities. Proc Am Thorac Soc 2008;5(8):857-64. http://dx.doi.org/ 10.1513/pats.200807-069TH

17. Adcock IM, Barnes PJ. Molecular mechanisms of corticosteroid resistance. Chest 2008;134(2):394-401. http://dx.doi.org/10.1378/chest.08-0440

18. Siva $\mathrm{R}$, Green $\mathrm{RH}$, Brightling $\mathrm{CE}$, et al. Eosinophilic airway inflammation and exacerbations of COPD: a randomised controlled trial. Eur Respir J 2007;29(5):90613. http://dx.doi.org/10.1183/09031936.00146306

19. Bafadhel M, McKenna S, Terry S, et al. Acute exacerbations of COPD: identification of biological clusters and their biomarkers. Am J Respir Crit Care Med 2011;184(6):662-71. http://dx.doi.org/10.1164/rccm.201104-05970C

20. Burge PS, Calverley PM, Jones PW, Spencer S, Anderson JA, Maslen TK. Randomised, double blind, placebo controlled study of fluticasone propionate in patients with moderate to severe chronic obstructive pulmonary disease: the ISOLDE trial. BMJ 2000;320:1297-303. http://dx.doi.org/10.1136/bmj.320.7245.1297

21. Jones PW, Willits LR, Burge PS, Calverley PM; Inhaled Steroids in Obstructive Lung Disease in Europe Study Investigators. Disease severity and the effect of fluticasone propionate on chronic obstructive pulmonary disease exacerbations. Eur Respir $J$ 2003;21(1):68-73. http://dx.doi.org/10.1183/09031936.03.00013303

22. Calverley P, Pauwels R, Vestbo J, et al. Combined salmeterol and fluticasone in the treatment of chronic obstructive pulmonary disease: a randomised controlled trial. Lancet 2003;361(9356):449-56. Erratum in: Lancet 2003;361:1660. http://dx.doi.org/10.1016/\$0140-6736(03)12459-2

23. Spencer S, Evans DJ, Karner C, Cates CJ. Inhaled corticosteroids versus long-acting beta(2)-agonists for chronic obstructive pulmonary disease. Cochrane Database Syst Rev 2011;10:CD007033. http://dx.doi.org/10.1002/14651858.CD007033.pub2

24. Calverley PM, Anderson JA, Celli B, et al. Salmeterol and fluticasone propionate and survival in chronic obstructive pulmonary disease. N Engl J Med 2007;356(8):775-89. http://dx.doi.org/10.1056/NEJMoa063070

25. Wedzicha JA, Calverley PM, Seemungal TA, Hagan G, Ansari Z, Stockley RA; INSPIRE Investigators. The prevention of chronic obstructive pulmonary disease exacerbations by salmeterol/fluticasone propionate or tiotropium bromide. Am J Respir Crit Care Med 2008;177(1):19-26. http://dx.doi.org/10.1164/rccm.200707-9730C

26. Aaron SD, Vandemheen $\mathrm{KL}$, Fergusson $\mathrm{D}$, et al. Tiotropium in combination with placebo, salmeterol, or fluticasone-salmeterol for treatment of chronic obstructive pulmonary disease: a randomized trial. Ann Intern Med 2007;146(8):545-55.

27. Suissa $S$, Ernst $P$, Vandemheen $\mathrm{KL}$, Aaron SD. Methodological issues in therapeutic trials of COPD. Eur Respir J 2008;31(5):927-33. http://dx.doi.org/10.1183/ 09031936.00098307

28. Donohue JF, Fogarty C, Lötvall J, et al. Once-daily bronchodilators for chronic obstructive pulmonary disease: indacaterol versus tiotropium. Am J Respir Crit Care Med 2010;182(2):155-62. http://dx.doi.org/10.1164/rccm.200910-15000C

29. Tashkin DP, Celli B, Senn S, et al. A 4-year trial of tiotropium in chronic obstructive pulmonary disease. N Engl J Med 2008;359(15):1543-54. http://dx.doi.org/10.1056/NEJMoa0805800

30. Niewoehner DE, Rice $\mathrm{K}$, Cote $\mathrm{C}$, et al. Prevention of exacerbations of chronic obstructive pulmonary disease with tiotropium, a once-daily inhaled anticholinergic bronchodilator: a randomized trial. Ann Intern Med 2005;143(5):317-26.

31. O'Donnell DE. Is sustained pharmacologic lung volume reduction now possible in COPD? Chest 2006;129(3):501-03. http://dx.doi.org/10.1378/chest.129.3.501

32. Washko GR, Fan VS, Ramsey SD, et al. The effect of lung volume reduction surgery on chronic obstructive pulmonary disease exacerbations. Am J Respir Crit Care Med 2008;177(2):164-9. http://dx.doi.org/10.1164/rccm.200708-11940C

33. Rabe KF. Treating COPD-the TORCH trial, P values, and the Dodo. N Engl I Med 2007;356:851-4. Erratum in N Engl J Med 2007;356(8):1692. http://dx.doi.org/10.1056/NEJMe068307

34. La Vecchia C, Fabbri LM. Prevention of death in COPD. N Engl J Med 2007;356(21):2211-2; author reply 2213-14. http://dx.doi.org/10.1056/ NEJMC070783

35. Celli BR, Thomas NE, Anderson JA, et al. Effect of pharmacotherapy on rate of decline of lung function in chronic obstructive pulmonary disease: results from the TORCH study. Am J Respir Crit Care Med 2008;178(4):332-8. http://dx.doi.org/10.1164/rccm.200712-18690C

36. Vestbo J, Edwards LD, Scanlon PD, et al. Changes in forced expiratory volume in 1 second over time in COPD. N Engl J Med 2011;365(13):1184-92. http://dx.doi.org/ 10.1056/NEJMoa1 105482

37. Jones PW, Bosh TK. Quality of life changes in COPD patients treated with salmeterol. 
Am J Respir Crit Care Med 1997;155(4):1283-9.

38. Kaplan A. Effect of tiotropium on quality of life in COPD: a systematic review. Prim Care Respir J 2010;19(4):315-25. http://dx.doi.org/10.4104/pcrj.2010.00067

39. Jones PW, Mahler DA, Gale R, Owen R, Kramer B. Profiling the effects of indacaterol on dyspnoea and health status in patients with COPD. Respir Med 2011;105(6):8929. http://dx.doi.org/10.1016/j.rmed.2011.02.013

40. Dahl R, Chung KF, Buhl R, et al. Efficacy of a new once-daily long-acting inhaled beta2-agonist indacaterol versus twice-daily formoterol in COPD. Thorax 2010;65(6):473-9. http://dx.doi.org/10.1136/thx.2009.125435

41. Chapman KR, Rennard SI, Dogra A, Owen R, Lassen C, Kramer B; INDORSE Study Investigators. Long-term safety and efficacy of indacaterol, a long-acting $\beta 2$-agonist, in subjects with COPD: a randomized, placebo-controlled study. Chest 2011;140(4):68-75. http://dx.doi.org/10.1164/rccm.200712-18690C

42. Barnes PJ, Adcock IM. Glucocorticoid resistance in inflammatory diseases. Lancet 2009;373(9678):1905-17. http://dx.doi.org/10.1016/S0140-6736(09)60326-3

43. Lipworth BJ. Systemic adverse effects of inhaled corticosteroid therapy: a systematic review and meta-analysis. Arch Intern Med 1999;159(9):941-55.

44. Farr BM, Bartlett CL, Wadsworth J, Miller DL; British Thoracic Society Pneumonia Study Group. Risk factors for community-acquired pneumonia diagnosed upon hospital admission. Respir Med 2000;94(10):954-63. http://dx.doi.org/ 10.1053/rmed.2000.0865

45. Gau JT, Acharya U, Khan S, Heh V, Mody L, Kao TC. Pharmacotherapy and the risk for community-acquired pneumonia. BMC Geriatr 2010;10:45. http://dx.doi.org/ 10.1186/1471-2318-10-45

46. Ernst P, Gonzalez AV, Brassard P, Suissa S. Inhaled corticosteroid use in chronic obstructive pulmonary disease and the risk of hospitalization for pneumonia. Am J Respir Crit Care Med 2007;176(2):162-6. http://dx.doi.org/10.1164/rccm.200611$16300 \mathrm{C}$

47. Kardos P, Wencker M, Glaab T, Vogelmeier C. Impact of salmeterol/fluticasone propionate versus salmeterol on exacerbations in severe chronic obstructive pulmonary disease. Am J Respir Crit Care Med 2007;175(2):144-9. http://dx.doi.org/10.1164/rccm.200602-2440C

48. Crim C, Calverley PM, Anderson JA, et al. Pneumonia risk in COPD patients receiving inhaled corticosteroids alone or in combination: TORCH study results. Eur Respir $J$ 2009;34(3):641-7. http://dx.doi.org/10.1183/09031936.00193908

49. Calverley PM, Stockley RA, Seemungal TA, et al. Reported pneumonia in patients with COPD: findings from the INSPIRE study. Chest 2011;139(3):505-12. http://dx.doi.org/10.1378/chest.09-2992

50. Nannini L, Cates CJ, Lasserson TJ, Poole P. Combined corticosteroid and long-acting beta-agonist in one inhaler versus placebo for chronic obstructive pulmonary disease. Cochrane Database Syst Rev 2007:4:CD003794. http://dx.doi.org/10.1002/ 14651858.CD003794.pub3

51. Sobieraj DM, White CM, Coleman Cl. Benefits and risks of adjunctive inhaled corticosteroids in chronic obstructive pulmonary disease: a meta-analysis. Clin Ther 2008;30(8):1416-25. http://dx.doi.org/10.1016/j.clinthera.2008.08.004

52. Singh S, Loke YK. Risk of pneumonia associated with long-term use of inhaled corticosteroids in chronic obstructive pulmonary disease: a critical review and update. Curr Opin Pulm Med 2010;16(2):118-22. http://dx.doi.org/10.1097/ MCP.0b013e328334c085

53. Rodrigo GJ, Castro-Rodriguez JA, Plaza V. Safety and efficacy of combined longacting beta-agonists and inhaled corticosteroids vs long-acting beta-agonists monotherapy for stable COPD: a systematic review. Chest 2009;136(4):1029-38. http://dx.doi.org/10.1378/chest.09-0821

54. Joo MJ, Au DH, Fitzgibbon ML, Lee TA. Inhaled corticosteroids and risk of pneumonia in newly diagnosed COPD. Respir Med 2010;104(2):246-52. http://dx.doi.org/10.1016/j.rmed.2009.10.002

55. Mapel D, Schum M, Yood M, Brown J, Miller D, Davis K. Pneumonia among COPD patients using inhaled corticosteroids and long-acting bronchodilators. Prim Care Respir J 2010;19(2):109-17. http://dx.doi.org/10.4104/pcrj.2009.00072

56. Sin DD, Tashkin D, Zhang $X$, et al. Budesonide and the risk of pneumonia: a metaanalysis of individual patient data. Lancet 2009;374(9691):712-19. http://dx.doi.org/10.1016/S0140-6736(09)61250-2

57. Hogg JC, Chu FS, Tan WC, et al. Survival after lung volume reduction in chronic obstructive pulmonary disease: insights from small airway pathology. Am J Respir Crit Care Med 2007;176(5):454-9. http://dx.doi.org/10.1164/rccm.200612-17720C

58. Jick SS, Lieberman ES, Rahman MU, Choi HK. Glucocorticoid use, other associated factors, and the risk of tuberculosis. Arthritis Rheum 2006;55(1):19-26. http://dx.doi.org/10.1002/art.21705

59. Brassard P, Suissa S, Kezouh A, Ernst P. Inhaled corticosteroids and risk of tuberculosis in patients with respiratory diseases. Am J Respir Crit Care Med 2011;183(5):675-8. http://dx.doi.org/10.1164/rccm.201007-10990C

60. Abdool-Gaffar MS, Ambaram A, Ainslie GM, et al. Guideline for the management of chronic obstructive pulmonary disease: 2011 update. S Afr Med J 2011;101(1 Pt 2):63-73. Erratum in S Afr Med J 2011;101:288.

61. Langhammer A, Forsmo S, Syversen U. Long-term therapy in COPD: any evidence of adverse effect on bone? Int J Chron Obstruct Pulmon Dis 2009:4:365-80. http://dx.doi.org/10.2147/COPD.S4797

62. Lee TA, Weiss KB. Fracture risk associated with inhaled corticosteroid use in chronic obstructive pulmonary disease. Am J Respir Crit Care Med 2004;169(7):855-9. http://dx.doi.org/10.1164/rccm.200307-9260C

63. Lehouck $A$, Boonen $S$, Decramer $M$, Janssens W. COPD, bone metabolism, and osteoporosis. Chest 2011;139(3):648-57. http://dx.doi.org/10.1378/chest.10-1427

64. Graat-Verboom L, van den Borne BE, Smeenk FW, Spruit MA, Wouters EF Osteoporosis in COPD outpatients based on bone mineral density and vertebral fractures. J Bone Miner Res 2011;26(3):561-8. ttp://dx.doi.org/10.1002/jbmr.257

65. Loke YK, Cavallazzi R, Singh S. Risk of fractures with inhaled corticosteroids in COPD: systematic review and meta-analysis of randomised controlled trials and observational studies. Thorax 2011;66(8):699-708. http://dx.doi.org/10.1136/ thx.2011.160028

66. Ebeling PR. Clinical practice. Osteoporosis in men. N Eng/ J Med 2008;358(14):147482. http://dx.doi.org/10.1056/NEJMcp0707217

67. Man SF, Sin DD. Thinning bone and inhaled corticosteroid in COPD: what to do until there is definitive proof? Chest 2009;136(6):1448-9. http://dx.doi.org/10.1378/ chest.09-1787

68. Pauwels RA, Löfdahl CG, Laitinen LA, et al. Long-term treatment with inhaled budesonide in persons with mild chronic obstructive pulmonary disease who continue smoking. European Respiratory Society Study on Chronic Obstructive Pulmonary Disease. N Engl J Med 1999;340(24):1948-53. http://dx.doi.org/ 10.1056/NEJM199906243402503

69. Tashkin DP, Murray HE, Skeans M, Murray RP. Skin manifestations of inhaled corticosteroids in COPD patients: results from Lung Health Study II. Chest 2004;126(4):1123-33. http://dx.doi.org/10.1378/chest.126.4.1123

70. Cumming RG, Mitchell P, Leeder SR. Use of inhaled corticosteroids and the risk of cataracts. $N$ Engl J Med 1997;337(1):8-14. http://dx.doi.org/10.1056/ NEJM199707033370102

71. Garbe E, Suissa S, LeLorier J. Association of inhaled corticosteroid use with cataract extraction in elderly patients. JAMA 1998:280:539-43. Erratum in JAMA 1998;280(6):1830. http://dx.doi.org/10.1001/jama.280.6.539

72. Smeeth $\mathrm{L}$, Boulis $\mathrm{M}$, Hubbard R, Fletcher AE. A population based case-control study of cataract and inhaled corticosteroids. $\mathrm{Br}$ J Ophthalmol 2003;87(10):1247-51. http://dx.doi.org/10.1136/bjo.87.10.1247

73. Ernst $P$, Baltzan M, Deschênes J, Suissa S. Low-dose inhaled and nasal corticosteroid use and the risk of cataracts. Eur Respir J 2006:27(6):1168-74 http://dx.doi.org/10.1183/09031936.06.00043005

74. Miller DP, Watkins SE, Sampson T, Davis KJ. Long-term use of fluticasone propionate/salmeterol fixed-dose combination and incidence of cataracts and glaucoma among chronic obstructive pulmonary disease patients in the UK General Practice Research Database. Int J Chron Obstruct Pulmon Dis 2011:6:467-76. http://dx.doi.org/10.2147/COPD.S14247

75. Suissa S, Kezouh A, Ernst P. Inhaled corticosteroids and the risks of diabetes onset and progression. Am J Med 2010;123(11):1001-06. http://dx.doi.org/ 10.1016/j.amjmed.2010.06.019

76. Sin DD, McAlister FA, Man SF, Anthonisen NR. Contemporary management of chronic obstructive pulmonary disease: scientific review. JAMA 2003;290(17):230112. http://dx.doi.org/10.1001/jama.290.17.2301

77. Yang IA, Fong KM, Sim EH, Black PN, Lasserson TJ. Inhaled corticosteroids for stable chronic obstructive pulmonary disease. Cochrane Database Syst Rev 2007:2:CD002991. http://dx.doi.org/10.1002/14651858.CD002991.pub2

78. Hurst JR, Vestbo J, Anzueto A, et al. Susceptibility to exacerbation in chronic obstructive pulmonary disease. N Engl J Med 2010;363(12):1128-38. http://dx.doi.org/10.1056/NEJMoa0909883

79. Jenkins CR, Celli B, Anderson JA, et al. Seasonality and determinants of moderate 
and severe COPD exacerbations in the TORCH study. Eur Respir J 2012;39(1):38-45. http://dx.doi.org/10.1183/09031936.00194610

80. Blais L, Bourbeau J, Sheehy O, LeLorier J. Inhaled corticosteroids in COPD: determinants of use and trends in patient persistence with treatment. Can Respir J 2004;11(1):27-32

81. Krigsman K, Moen J, Nilsson JL, Ring L. Refill adherence by the elderly for asthma/chronic obstructive pulmonary disease drugs dispensed over a 10-year period. J Clin Pharmacol Ther 2007;32(6):603-11. http://dx.doi.org/10.1111/j.13652710.2007.00866.x

82. Schermer TR, Hendriks AJ, Chavannes NH, et al. Probability and determinants of relapse after discontinuation of inhaled corticosteroids in patients with COPD treated in general practice. Prim Care Respir J 2004;13(1):48-55. http://dx.doi.org/10.1016/j.pcrj.2003.11.005

83. van der Valk P, Monninkhof E, van der Palen J, Zielhuis G, van Herwaarden C. Effect of discontinuation of inhaled corticosteroids in patients with chronic obstructive pulmonary disease: the COPE study. Am J Respir Crit Care Med 2002;166(10):135863. http://dx.doi.org/10.1164/rccm.200206-5120C

84. Choudhury $A B$, Dawson $C M$, Kilvington $H E$, et al. Withdrawal of inhaled corticosteroids in people with COPD in primary care: a randomised controlled trial. Respir Res 2007;8:93. http://dx.doi.org/10.1186/1465-9921-8-93

85. Wouters EF, Postma DS, Fokkens B, et al. Withdrawal of fluticasone propionate from combined salmeterol/fluticasone treatment in patients with COPD causes immediate and sustained disease deterioration: a randomised controlled trial. Thorax 2005;60:480-7. http://dx.doi.org/10.1136/thx.2004.034280

86. Nadeem NJ, Taylor SJ, Eldridge SM. Withdrawal of inhaled corticosteroids in individuals with COPD: a systematic review and comment on trial methodology. Respir Res 2011;12:107. http://dx.doi.org/10.1186/1465-9921-12-107

\section{Available online at http://www.thepcrj.org}

